\title{
Pollen tube growth and inhibition in distylous and homostylous Turnera and Piriqueta (Turneraceae)
}

\author{
Farshad Tamari, Andreas Athanasiou, and Joel S. Shore
}

\begin{abstract}
We investigate sites of incompatibility for five Turnera L. species and for Piriqueta caroliniana (Walt.) Urban using aniline blue staining of pollen tubes and fluorescence microscopy. We show that sites of incompatibility occur in the stigma and upper regions of the style. There is an asymmetry between the morphs where, following selfing, pollen tubes tend to grow further into long-styled compared to short-styled plants, although the difference is not particularly marked. We demonstrate for the first time a qualitative difference in the appearance of pollen tubes. Upon self-pollination, pollen tubes in short-styled plants do not produce callose plugs, while all other pollinations result in callose plug formation. This could indicate that there is a difference in the mechanisms of incompatibility between the morphs. Exploiting crosses between two populations of Turnera scabra Millsp. that differ in flower size, we found no support for the hypothesis that incompatibility of long-styled plants is the result of insufficient nutrient reserves in pollen. Bud-pollinations provided limited support for the hypothesis that a short-specific style protein is involved in incompatibility. Crosses between distylous and homostylous species provided support for a recombinant origin for homostyly for four species, while deviations from this expectation were observed in four instances.
\end{abstract}

Key words: distyly, homostyly, self-incompatibility, callose, pollen tubes, Turnera.

Résumé : Les auteurs ont étudié les sites d'incompatibilité chez cinq espèces de Turnera L. et chez le Piriqueta caroliniana (Walt.) Urban, en utilisant la microscopie en fluorescense après avoir coloré les tubes polliniques au bleu d'aniline. On montre qu'il y a des sites d'incompatibilité dans les stigmates et dans les régions supérieures du style. Il y a asymétrie entre les morphes où, suite à l'autofécondation, les tubes polliniques ont tendance à pousser plus loin dans les styles longs que dans les styles courts, bien que la différence ne soit pas très marquée. On démontre pour la première fois une différence qualitative dans l'apparence des tubes polliniques. Suite à l'auto-pollinisation, chez les plantes à styles courts, les tubes polliniques ne produisent pas de bouchon de callose, alors que dans toutes les autres pollinisations il y formation de bouchons de callose. Ceci suggère une différence dans les mécanismes d'incompatibilité entre les morphes. En exploitant les croisements entre deux populations du Turnera scabra Millsp., qui diffèrent selon la dimension de leurs fleurs, les auteurs n'ont trouvé aucune preuve supportant l'hypothèse que l'incompatibilité chez les plantes à styles longs résulterait de réserves nutritives insuffisantes dans le pollen. Les pollinisations des bourgeons n'offrent qu'un support limité à l'idée qu'une protéine spécifique aux fleurs à style court, serait impliquée dans l'incompatibilité. Les croisements entre les espèces distyles et homostyles supportent l'idée de l'origine recombinatoire pour l'homostylie chez quatre espèces, alors qu'on observe des déviations par rapport à cette attente dans quatre cas.

Mots clés : distylie, homostylie, auto-compatibilité, callose, tubes polliniques, Turnera.

[Traduit par la Rédaction]

\section{Introduction}

A growing body of data on pollen tube growth in heterostylous species has revealed considerable heterogeneity in sites of inhibition. This work has been reviewed by Dulberger (1992) and Barrett and Cruzan (1994). Wedderburn and Richards (1990) have carried out an extensive study of 52 species of Primula, and Bawa and Beach (1983) have examined nine distylous species in the Rubiaceae.

Received March 19, 2001. Published on the NRC Research Press Web site on May 9, 2001.

F. Tamari, A. Athanasiou, and J.S. Shore. ${ }^{1}$ Department of Biology, York University, Toronto, ON M3J 1P3, Canada.

${ }^{1}$ Corresponding author (e-mail: shore@yorku.ca).
Given that heterostyly has evolved independently on at least 20 occasions among angiosperm families (Barrett 1992), it is not wholly unexpected that the results of these studies are heterogeneous, showing different self-incompatibility (SI) responses at varying sites among taxa. Pollen tube inhibition in heterostylous species occurs at all possible levels from the stigma surface in many species (Baker 1966; Wedderburn and Richards 1990; Dulberger 1992) to the ovary (Dulberger 1964; Schou and Philipp 1983; Anderson and Barrett 1986; Scribailo and Barrett 1991; Sage et al. 1999). Some authors have suggested that multiple sites of inhibition occur within an individual style (Shivanna et al. 1981; Wedderburn and Richards 1990). For some species, sites of SI are identical for both morphs (Baker 1966; Dulberger 1975a; Murray 1990; Wedderburn and Richards 1990), while for others a common pattern is for greater pollen tube penetration of the long-styled morph (Wedderburn and Richards 1990; 
Dulberger 1992; Wong et al. 1994b). Greater incompatible pollen tube penetration of short-styled plants occurs infrequently (Lewis 1982; Scribailo and Barrett 1991).

An investigation of the sites of SI may be helpful in gaining an understanding of the unknown mechanism(s) of selfincompatibility in heterostylous species (Barrett 1998). Mather and deWinton (1941), Dulberger (1975b, 1992), and Lloyd and Webb (1992), have suggested that there might be a very close and possibly causal connection between aspects of floral polymorphism and the mechanism(s) of incompatibility in heterostylous species (although see Wedderburn and Richards 1990). Some of the evidence supporting this view comes from observations of differences in the sites of pollen tube inhibition in the two morphs. For example, Scribailo and Barrett (1991) have suggested that insufficient pollen reserves could account for the SI response of long-styled plants of Pontederia sagittata. In contrast, Schoch-Bodmer (1934) provided evidence that insufficient reserves cannot account for the SI reponse of long-styled plants of Fagopyrum esculentum.

We explore the sites of incompatibility in five Turnera species and in Piriqueta caroliniana (Turneraceae), in an effort to gain insights into the mechanisms of self-incompatibility. Athanasiou and Shore (1997) discovered a protein unique to styles of short-styled plants. The protein appeared late in development and was absent from style extracts $24 \mathrm{~h}$ prior to anthesis, implicating it in the incompatibility response. We use bud-pollinations performed prior to the appearance of this protein, to test the hypothesis that the style protein is involved in the SI response. We also use crosses between two populations of Turnera scabra to test the insufficient pollen reserves hypothesis for incompatibility in long-styled plants.

A number of self-compatible, homostylous species of Turnera occur and all those investigated within the series Canaligerae (Urban 1883) appear to be either hexaploids or octaploids (Barrett and Shore 1987; Fernandez 1987). Interestingly, homostyles derived via a crossover within the putative distyly supergene are expected to exhibit a particular pattern of "residual" incompatibility when crossed to distylous species (Ernst 1955; Dowrick 1956; Baker 1975). Barrett and Shore (1987) carried out crosses between distylous and three homostylous species of Turnera and found that the results of crosses (assessed by fruit set following crosses) were consistent with the hypothesis that the homostyles had arisen via recombination within a supergene controlling distyly. Segregation data were also consistent with the hypothesis (Shore and Barrett 1985). Here we expand our analysis to additional homostylous species using pollen tube growth data.

The specific objectives of this study were as follows: $(i)$ to determine sites of incompatibility for six distylous species in the Turneraceae; ( $i i)$ to examine the time of onset of selfincompatibility in T. scabra and Turnera joelii using budpollinations; (iii) to examine the time course of pollen tube growth for compatible and incompatible pollinations for T. scabra; (iv) to test the hypothesis that insufficient pollen reserves might account for incompatibility of long-styled plants of T. scabra; and, (v) to test the recombinant hypothesis for the origin of homostyly in Turnera acuta, Turnera aurelii, Turnera cuneiformis, Turnera orientalis, Turnera velutina, Turnera ulmifolia, and Piriqueta cistoides by crossing distylous and homostylous species. Authority names for species used in this study are given in Table 1.

\section{Materials and methods}

\section{Plant species and experimental conditions}

This study was conducted in a pollinator-free greenhouse at York University, Toronto, Canada, beginning September 1997. Greenhouse temperatures were recorded daily over the course of the pollinations and averaged $27.4 \pm 2.6^{\circ} \mathrm{C}$ (mean $\pm \mathrm{SD}$ ). Plants used in the study were 1-3 years of age and were grown in $10 \mathrm{~cm}$ pots in standard potting soil and watered once or twice daily. Most species and populations were originally sampled as seeds taken from natural populations. Some plants were derived from seeds that had been produced after 1-4 generations of growth under greenhouse conditions. Plants from Quaco Rock, Jamaica were obtained from rooted cuttings sampled in the field. The plant populations and sample locations are listed in Table 1.

All species studied have ephemeral flowers that open on a single morning, for approximately $3-7 \mathrm{~h}$, depending on the species and temperature. Plants of T. cuneiformis and T. orientalis are exceptional and open at or around noon. Most of the species examined are small shrubs commonly found along road sides and in disturbed sites. Turnera grandiflora, $P$. caroliniana, and $P$. cistoides are herbaceous. Six of the species are distylous (Table 1), possessing reciprocal herkogamy, and a rigid self-incompatibility system preventing seed set following self- and intra-morph pollinations. Seven species do not exhibit distyly, and are self-compatible, often having styles and stamens in close proximity within a flower. We refer to these species as having a homostylous breeding system.

\section{Sites of incompatibility}

To investigate sites of pollen tube inhibition, a number of selfand inter-morph pollinations were performed in the morning. Pollinations were performed by removing anthers, with a pair of fine forceps, and gently brushing 1-3 anthers across the highly branched stigmatic surfaces. We ensured that ample pollen was placed on stigmatic surfaces for all pollination treatments. Results of crosses are listed with the maternal plant first followed by the pollen parent. Forceps were rinsed in $95 \%$ ethanol and wiped dry after each pollination. Styles were collected approximately $24 \mathrm{~h}$ after pollination and fixed as described below.

\section{Pollen tube growth}

To explore the rate of pollen tube growth and the development of callose plugs, we carried out timed self- and inter-morph pollinations using two populations of $T$. scabra. Pollinations were performed as above and styles were harvested 15, 30, 45, 60, and $120 \mathrm{~min}$ after pollination. Styles were fixed and stained for microscopy (see below).

\section{Bud-pollinations}

Pollen from an open flower of one of the morphs was used to pollinate flower buds of both long- and short-styled plants that were dissected open one day prior to anthesis. Buds are easily opened by removing the sepals and then carefully unrolling the petals. Styles were harvested approximately $24 \mathrm{~h}$ after pollination, fixed, and stained. We explored the effects of bud-pollinations for three populations of T. scabra and for T. joelii. Both morphs were bud-selfed and reciprocally crossed to the opposite morph.

\section{Pollen size and incompatibility}

To explore the influence of pollen size on incompatibility for long-styled plants, we performed crosses between a large-flowered 
Table 1. Localities, breeding systems, and ploidy levels of Turnera and Piriqueta species sampled.

\begin{tabular}{|c|c|c|c|}
\hline Code & Species & Ploidy level & Locality \\
\hline \multicolumn{4}{|c|}{ Distylous species } \\
\hline Nica & T. scabra Millspaugh & $2 \times$ & Managua, Nicaragua \\
\hline Mrgd & T. scabra Millspaugh & $2 \times$ & Margarita Island, Venezuela \\
\hline Mrgh & T. scabra Millspaugh & $2 \times$ & Margarita Island, Venezuela \\
\hline Cosr & T. scabra Millspaugh & $2 \times$ & Taboga, Costa Rica \\
\hline Dor4 & T. scabra Millspaugh & $4 \times$ & Dominican Republic \\
\hline Dor7 & T. scabra Millspaugh & $4 \times$ & Dominican Republic \\
\hline Subu & T. subulata Smith & $4 \times$ & Recife, Brazil \\
\hline Krpo & T. krapovickasii Arbo & $2 \times$ & Paraguay \\
\hline Joli & T. joelii Arbo & $2 \times$ & Rio Juremal, Brazil \\
\hline Gran & T. grandiflora (Urban)Arbo & $2 \times$ & Corrientes, Argentina \\
\hline Pird & P. caroliniana (Walt.)Urban & $2 \times$ & Crawfordville, Florida \\
\hline \multicolumn{4}{|c|}{ Homostylous species } \\
\hline Ulmi & T. ulmifolia $\mathrm{L}$. & $6 x$ & Jamaica \\
\hline Quac & T. ulmifolia $\mathrm{L}$. & $6 x$ & Quaco Rock, Jamaica \\
\hline Baha & T. acuta (Urban) Arbo & $6 x$ & Pelican Lake, Bahamas \\
\hline Orie & T. orientalis (Urban) Arbo & $6 x$ & Corrientes, Argentina \\
\hline Velu & T. velutina (Urban) Arbo & $6 \times$ & Mexico \\
\hline Cune & T. cuneiformis (Urban) Arbo & $8 \times$ & Pirapora, Brazil \\
\hline Aure & T. aurelii Arbo & $8 \times$ & Paraguay \\
\hline Pirh & P. cistoides (L.) Griseb. & $2 \times$ & Jamaica \\
\hline
\end{tabular}

population of T. scabra from Managua, Nicaragua and a smallflowered population of $T$. scabra from Margarita Island, Venezuela. We measured style length, stamen length, and flower diameter of plants for both populations with a pair of calipers. Pollen length and width were measured using a compound microscope equipped with a calibrated ocular micrometer. Long-styled plants from the small-flowered population were self-pollinated and pollinated with pollen from long-styled plants of the large-flowered population. Additional controls involved pollinations between morphs of the two populations. Styles were fixed and stained for fluorescence microscopy.

\section{Crosses of distylous and homostylous species}

Pollinations were performed between six populations of three self-incompatible distylous species and seven self-compatible homostylous species. We paired each homostylous species with just one distylous population for the crosses. All four combinations of pollinations were carried out (i.e., long $\times$ homostyle, homostyle $\times$ long, short $\times$ homostyle, homostyle $\times$ short). Pollinations were performed as detailed above with the exception that flowers of homostylous plants were emasculated one day prior to anthesis to avoid pollen contamination resulting from the close proximity of anthers and stigmas. Styles were collected approximately $24 \mathrm{~h}$ after pollination, fixed, and stained as described below.

\section{Fixation and staining}

Approximately $24 \mathrm{~h}$ after pollination, styles were removed from flowers and placed in $1.0 \mathrm{~mL}$ of freshly made aceto-alcohol solution ( 3 ethanol : 1 glacial acetic acid) in a microfuge tube. The fixative was replaced with an equal volume of aceto-alcohol within 1$5 \mathrm{~h}$. Styles were stored at $4^{\circ} \mathrm{C}$ for subsequent staining and microscopic observation. Styles were stained using a modification of Martin's (Martin 1959) protocol. The fixative was removed from each microfuge tube and styles were washed in three changes of water for 1-3 min at each washing step. Preliminary trials revealed that treatment of the styles with $8 \mathrm{M} \mathrm{NaOH}$ rendered the stigmatic branches very dark brown and, thus, not observable by microscopy. As a consequence, this step was omitted. To stain pollen tubes, we used $0.1 \%(\mathrm{w} / \mathrm{v})$ water-soluble aniline blue in $0.1 \mathrm{M} \mathrm{K}_{3} \mathrm{PO}_{4}$, stored at $4{ }^{\circ} \mathrm{C}$. Styles were immersed in the stain for a minimum of $8 \mathrm{~h}$ prior to microscopic observation.

\section{Microscopy}

Observations of pollen tube germination, penetration through the stigma, and elongation into the style were scored using an epifluorescence microscope (Leitz, Dialux 20EB with BP340-380 excitation filter, RKP400 beam splitting mirror, and LP430 barrier filter). We recorded whether pollen tubes had reached the base of the style and whether callose plugs had formed in pollen tubes. For some styles, bright field and fluorescence microscopy were used. Since numerous pollen tubes are present following self-pollination, it was not possible to quantify the position of each. Therefore, the position at which the majority of pollen tubes stopped was measured, as well as the length of the longest pollen tube and style length, with a calibrated ocular micrometer. Photomicrographs were taken using a Wild Leitz, Wild MPS46 Photoautomat mounted on the microscope and Kodak Elite II 400, 35mm, EL 135-36 film.

\section{Statistical analyses}

Tests of independence (Fisher's exact test for $2 \times 2$ tables, and the $G$ statistic for other tables) were used to analyze the proportion of pollen tube penetration into the styles, presence or absence of pollen tubes at the base of the styles, and the presence or absence of callose plugs. Analysis of variance followed by Scheffé's a posteriori test were carried out using PROC GLM and type III sums of squares of SAS (1996) for comparisons of majority inhibition sites, and longest pollen tube inhibition lengths.

\section{Results}

\section{Site of incompatibility}

Control inter-morph pollinations always revealed that pollen tubes reached the base of the styles (e.g., Fig. 1). We measured the distance traversed by the longest pollen tube (Fig. 2; Table 2) and the position at which the next largest aggregation 
Figs. 1-4. Pollen tubes in styles fixed $24 \mathrm{~h}$ after pollination and stained with aniline blue. Fig. 1. Brightly fluorescing pollen tubes at the base of a style for the compatible cross of a short-styled plant of Turnera scabra, from Margarita Island. Fig. 2. Pollen tube inhibition in the style following self-pollination of a long-styled plant of T. scabra, from Costa Rica. Arrow indicates the longest pollen tube. Fig. 3. Brightly fluorescing callose plugs in the style of a short-styled plant of T. scabra from Nicaragua, following compatible pollination. Fig. 4. Many pollen tubes are visible at the base of the style following self-pollination of a bud of a shortstyled plant of T. scabra from Nicaragua. Scale bar $=100 \mu \mathrm{m}$.

of pollen tubes appears to stop in the style (Table 2). We refer to this location as the majority site of inhibition.

In all instances, and for both morphs, pollen germinates and pollen tubes penetrate into the stigma (data not shown). To test whether pollen tubes penetrate into the style to a greater extent in one morph versus the other, we carried out tests of independence using Fisher's exact test. For 8 of the 11 populations, a statistically greater proportion of styles were penetrated for long-styled than for short-styled plants (Table 2). Over all populations and species when long-styled plants are selfed, pollen tubes grow into the stigma and, in $97.4 \%$ of pollinations, tubes have penetrated into the styles. For short-styled plants, pollen germinates, pollen tubes penetrate the stigma, and in $63.4 \%$ of pollinations, tubes have penetrated into the styles. In the remaining $36.6 \%$ of cases, pollen germinates and pollen tubes grow into the stigma but do not penetrate into the style. In no instance did we observe a pollen tube penetrating to the base of the style following self-pollination of either morph for any of the distylous populations or species.

For all populations and species, both the majority of pollen tubes and the longest pollen tubes grow to a greater extent when long-styled plants are selfed, in contrast to shortstyled plants (Table 2). The majority of pollen tubes penetrate approximately $3.1 \pm 0.5 \mathrm{~mm}$ into long styles compared to $1.2 \pm 0.7 \mathrm{~mm}$ for short-styled plants. The mean for the longest pollen tubes for selfed, long-styled plants is $4.0 \pm$ $1.9 \mathrm{~mm}$ compared with $1.6 \pm 1.0 \mathrm{~mm}$ for short-styled plants. Two-way ANOVA (Table 3) revealed that these differences are statistically significant, and that there are significant population and population $\times$ morph interaction effects, indicating that the difference in growth varies depending on the population and species examined.

During our initial investigations we discovered what appeared to be a qualitative difference in the presence of callose plugs upon selfing long- versus short-styled plants. Callose plugs are regularly formed in pollen tubes of both morphs during pollen tube growth following inter-morph pollination (Fig. 3) and often in self-pollinations of buds of long- and short-styled plants (Fig. 4). We recorded whether callose plugs were present or absent for all self- and intermorph pollinations. There is a marked and statistically significant difference in the presence of callose plugs among pollination treatments (Table 4). Callose plugs do not generally occur upon selfing, short-styled plants (Figs. 6, 9, 12, 15, and 18) but appear at high frequency upon crossing short-styled plants with pollen from long-styled plants (Fig. 3; Table 4). Long-styled plants form callose plugs
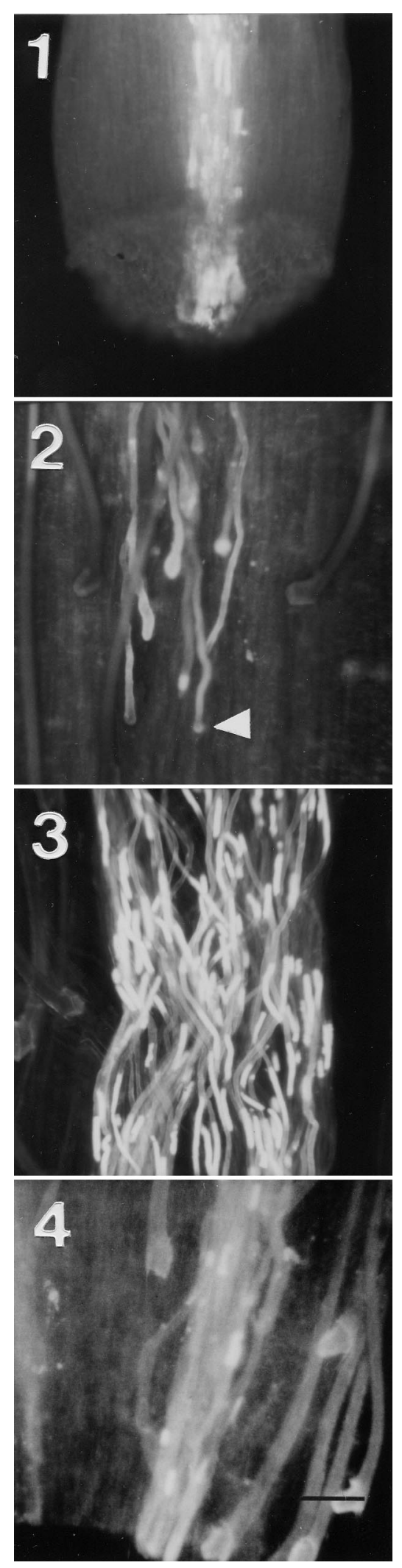

when they are both selfed or crossed (Figs. 5, 8, 11, 14, and 17; Table 4). This finding holds across the five species of Turnera and in P. caroliniana. The absence of brightly fluorescent callose plugs sometimes makes it difficult to observe pollen tubes using fluorescence microscopy (Figs. 6, 9, 12, 
Table 2. Characteristics of pollen tubes $24 \mathrm{~h}$ after self-pollination of Turnera and Piriqueta species.

\begin{tabular}{|c|c|c|c|c|c|c|c|}
\hline \multicolumn{2}{|c|}{ Species: population } & \multirow{2}{*}{$\frac{N}{23}$} & \multirow{2}{*}{$\begin{array}{c}\begin{array}{c}\text { No. Styles } \\
\text { with tubes }\end{array} \\
23\end{array}$} & \multirow{2}{*}{$\frac{P}{\mathrm{~ns}}$} & \multirow{2}{*}{$\begin{array}{l}\text { Style length } \\
(\mathrm{mm})\end{array}$} & \multirow{2}{*}{$\begin{array}{l}\text { Majority of } \\
\text { tubes }(\mathrm{mm})\end{array}$} & \multirow{2}{*}{$\begin{array}{l}\begin{array}{l}\text { Longest } \\
\text { tube }(\mathrm{mm})\end{array} \\
6.3 \pm 2.4\end{array}$} \\
\hline Nica & $\mathrm{L}$ & & & & & & \\
\hline & $\mathrm{S}$ & 20 & 20 & & $6.0 \pm 0.6$ & $1.8 \pm 0.8$ & $2.4 \pm 0.6$ \\
\hline \multirow[t]{2}{*}{ Mrgd } & $\mathrm{L}$ & 23 & 21 & 0.028 & $7.6 \pm 0.6$ & $2.5 \pm 1.6$ & $3.3 \pm 2.2$ \\
\hline & $\mathrm{S}$ & 20 & 12 & & $4.7 \pm 0.5$ & $1.1 \pm 0.4$ & $1.3 \pm 0.9$ \\
\hline \multirow[t]{2}{*}{ Mrgh } & $\mathrm{L}$ & 20 & 20 & 0.048 & $9.0 \pm 1.0$ & $3.3 \pm 0.8$ & $4.1 \pm 1.0$ \\
\hline & $\mathrm{S}$ & 21 & 16 & & $4.8 \pm 0.4$ & $1.4 \pm 0.5$ & $1.6 \pm 0.7$ \\
\hline \multirow[t]{2}{*}{ Cosr } & $\mathrm{L}$ & 22 & 21 & ns & $11.1 \pm 0.5$ & $5.2 \pm 1.7$ & $5.8 \pm 2.0$ \\
\hline & $\mathrm{S}$ & 23 & 23 & & $6.0 \pm 0.6$ & $1.4 \pm 0.4$ & $2.6 \pm 1.0$ \\
\hline \multirow[t]{2}{*}{ Dor4 } & $\mathrm{L}$ & 23 & 23 & ns & $9.7 \pm 0.8$ & $2.5 \pm 0.6$ & $3.4 \pm 0.7$ \\
\hline & $\mathrm{S}$ & 21 & 20 & & $5.8 \pm 0.6$ & $1.6 \pm 0.4$ & $2.0 \pm 0.4$ \\
\hline \multirow[t]{2}{*}{ Dor7 } & $\mathrm{L}$ & 20 & 20 & 0.003 & $10.8 \pm 1.0$ & $2.3 \pm 0.3$ & $3.1 \pm 0.4$ \\
\hline & S & 21 & 13 & & $6.8 \pm 0.5$ & $1.8 \pm 0.6$ & $2.0 \pm 0.9$ \\
\hline \multirow[t]{2}{*}{ Subu } & $\mathrm{L}$ & 20 & 19 & $<0.001$ & $10.7 \pm 0.5$ & $1.8 \pm 0.3$ & $2.3 \pm 0.4$ \\
\hline & S & 20 & 7 & & $5.4 \pm 0.3$ & $0.9 \pm 0.4$ & $1.2 \pm 0.5$ \\
\hline \multirow[t]{2}{*}{ Krpo } & $\mathrm{L}$ & 22 & 22 & $<0.001$ & $10.3 \pm 0.6$ & $2.5 \pm 0.5$ & $2.9 \pm 0.7$ \\
\hline & S & 20 & 0 & & $4.7 \pm 0.2$ & $0.2 \pm 0.0$ & $0.2 \pm 0.0$ \\
\hline \multirow[t]{2}{*}{ Joli } & $\mathrm{L}$ & 20 & 20 & 0.020 & $10.5 \pm 0.6$ & $2.2 \pm 0.6$ & $2.9 \pm 0.8$ \\
\hline & $\mathrm{S}$ & 20 & 14 & & $6.3 \pm 0.3$ & $1.2 \pm 0.1$ & $1.4 \pm 0.2$ \\
\hline \multirow[t]{2}{*}{ Gran } & $\mathrm{L}$ & 21 & 19 & 0.013 & $17.2 \pm 0.6$ & $2.4 \pm 0.9$ & $4.2 \pm 2.6$ \\
\hline & $\mathrm{S}$ & 21 & 14 & & $10.7 \pm 0.6$ & $1.5 \pm 0.9$ & $2.2 \pm 1.4$ \\
\hline \multirow[t]{2}{*}{ Pird } & $\mathrm{L}$ & 20 & 20 & $<0.001$ & $6.3 \pm 0.6$ & $4.1 \pm 1.3$ & $5.0 \pm 0.8$ \\
\hline & $\mathrm{S}$ & 20 & 5 & & $2.9 \pm 0.5$ & $0.6 \pm 0.6$ & $0.6 \pm 0.6$ \\
\hline \multirow[t]{2}{*}{ Mean } & $\mathrm{L}$ & 234 & 228 & $<0.001$ & $10.5 \pm 2.8$ & $3.1 \pm 0.5$ & $4.0 \pm 1.9$ \\
\hline & $\mathrm{S}$ & 227 & 144 & & $5.9 \pm 1.9$ & $1.2 \pm 0.7$ & $1.6 \pm 1.0$ \\
\hline
\end{tabular}

Note: $N$ is the number of styles examined; No. of styles with tubes penetrating into the styles; $P$, the probability from a test of independence comparing the proportion of styles with pollen tubes, for long- versus short-styled plants (L and S, respectively), using Fisher's exact test for each population. Values are mean \pm SD for length of style, distance traversed by the majority of pollen tubes, and the longest tube. ns, not statistically significant. Species: population abbreviations as in Table 1.

Table 3. Two way ANOVA for pollen tube growth $24 \mathrm{~h}$ after self-pollination.

\begin{tabular}{|c|c|c|c|c|c|}
\hline \multirow[b]{2}{*}{ Source } & \multirow[b]{2}{*}{ df } & \multicolumn{2}{|c|}{ Majority of tubes } & \multicolumn{2}{|c|}{ Longest tubes } \\
\hline & & MS & $F$ & MS & $F$ \\
\hline Morph & 1 & 411.7 & $505.8 * * *$ & 646.6 & $435.6^{* * *}$ \\
\hline Population & 10 & 24.3 & $29.8 * * *$ & 33.9 & $22.8 * * *$ \\
\hline Population $\times$ morph & 10 & 17.4 & $21.4 * * *$ & 13.0 & $8.8 * * *$ \\
\hline Residual & 460 & 0.8 & - & 1.5 & - \\
\hline
\end{tabular}

15 , and 18), but tubes are clearly present when viewed using bright field light microscopy (Figs. 7, 10, 13, 16, and 19).

To explore the nature of the difference in callose plug formation, we examined pollen tubes in a series of pollinations to determine the time course for the development of pollen tubes and callose plugs. We plot mean pollen tube lengths (expressed as percent of style length) that were sampled over a $2 \mathrm{~h}$ period for self- and inter-morph pollinations for two populations of $T$. scabra (Fig. 20). Pollen tubes begin to grow within approximately $30 \mathrm{~min}$ following pollination and compatible pollen tubes have grown over $60 \%$ of the length of the styles after $2 \mathrm{~h}$, for the Nicaraguan population (Fig. 20a), and to approximately $80 \%$ for the Costa Rican population (Fig. 20b). For self-pollinations, pollen tubes begin growing on a similar trajectory, but little or no growth seems to occur after about $1 \mathrm{~h}$. Pollen tubes for selfed, longstyled plants continue to increase in length somewhat beyond $1 \mathrm{~h}$ for the Nicarguan population (Fig. 20a). Interest- ingly, pollen tubes of both morphs grow at different absolute rates (data not shown). For the compatible crosses, pollen from short-styled plants grows at a greater absolute rate compared with pollen from long-styled plants. When growth is measured as a percent of style length, however, growth rates are nearly equivalent (Figs. $20 a$ and 20b).

Callose plugs first appear in styles approximately $30 \mathrm{~min}$ after pollination, and are initially small in size. The percent of styles having pollen tubes with callose plugs increases rapidly reaching about $100 \%$ at $2 \mathrm{~h}$ (Figs. $21 a$ and $21 b$ ). Callose plugs did not appear when short-styled plants were self-pollinated, but appeared in all other pollinations. We have recently examined some additional styles, and have found a small number of short styles with very few callose plugs in their stigmas.

\section{Bud-pollinations}

Athanasiou and Shore (1997) showed, using silver-stained 
Table 4. Number of styles possessing callose plugs $24 \mathrm{~h}$ after self- and inter-morph pollinations of Turnera and Piriqueta species.

\begin{tabular}{lccccr}
\hline Species: population & Long $\times$ short & Short $\times$ long & Long $\times$ long & Short $\times$ short & $G_{\mathrm{df}=3}$ \\
\hline Nica* & - & - & $23 / 23$ & $0 / 20$ & $59.4^{* * *}$ \\
Mrgd & $19 / 19$ & $19 / 20$ & $23 / 23$ & $0 / 20$ & $85.4^{* * *}$ \\
Mrgh & $22 / 22$ & $18 / 20$ & $20 / 20$ & $0 / 21$ & $85.0^{* * *}$ \\
Cosr* & - & - & $22 / 22$ & $0 / 23$ & $62.4^{* * *}$ \\
Dor4 & $21 / 21$ & $17 / 22$ & $23 / 23$ & $0 / 21$ & $82.5 * * *$ \\
Dor7 & $24 / 24$ & $18 / 20$ & $20 / 20$ & $0 / 21$ & $86.3^{* * *}$ \\
Subu & $17 / 20$ & $24 / 42$ & $20 / 20$ & $0 / 20$ & $63.2^{* * *}$ \\
Krpo* & - & - & $22 / 22$ & $0 / 20$ & $58.1^{* * *}$ \\
Joli & $20 / 20$ & $20 / 20$ & $20 / 20$ & $0 / 20$ & $90.0^{* * *}$ \\
Gran* & - & - & $21 / 21$ & $0 / 21$ & $58.2^{* * *}$ \\
Pird & $19 / 22$ & $17 / 20$ & $20 / 20$ & $0 / 20$ & $68.0^{* * *}$ \\
Pooled & $142 / 148$ & $133 / 164$ & $234 / 234$ & $0 / 227$ & $783.4 * * *$ \\
\hline
\end{tabular}

Note: Table entries are the number of styles with pollen tubes containing callose plugs per total number of styles

examined. $G$ tests of independence were performed for each population. Species: population abbreviations as in Table 1.

*We did not record the presence or absence of callose plugs for intermorph pollinations for these populations, and $\mathrm{df}=1$.

$* * * P<0.001$

isoelectric focusing gels, that a putative incompatibility protein found only in styles of short-styled plants was not present $24 \mathrm{~h}$ prior to anthesis. We carried out bud-pollinations to test whether this might be an incompatibility protein (Table 5). Pollen tubes do reach the base of the style for some crosses (Table 5; Fig. 4), with greater proportions reaching the base for compatible compared to incompatible crosses and there are significant differences using the $G$ test for independence (Table 5). For T. joelii, a greater proportion of tubes reaches the base of the style for selfed, short-styled plants compared to selfed, long-styled plants $\left(G_{\mathrm{df}=3}=30.6\right.$, $P<0.001)$, but the differences between short-styled and long-styled plants are not particularly marked for the other populations. Furthermore, pollen tubes grow to a lesser degree upon selfing as opposed to inter-morph crosses for the majority site of inhibition, while the longest tube seems to penetrate more deeply for the cross long $x$ short. Two-way ANOVA (Table 6) revealed a significant effect of cross, population, and interaction for the pollen tube growth characters.

\section{Pollen size and incompatibility}

Since there is a pollen size and style length dimorphism in Turnera, it is possible that self-incompatibility in long-styled plants results from insufficent reserves to support pollen tube growth through the long styles. In other words, there may be no active incompatibility mechanism present at all, and small pollen size, at least for long-styled plants, could explain the inability of self pollen tubes to grow the entire length of styles. We measured a number of floral characters distinguishing two divergent populations of $T$. scabra (Table 7): flower diameter is significantly greater for the Nicaraguan in contrast to the Margarita Island population and this pattern holds for all characters measured. Both populations exhibit the usual dimorphisms of style, stamen length, and pollen size (Table 7). Interestingly, both the length and diameter of pollen from the long-styled plants of the larger flowered Nicaraguan population are the same as the length and width of pollen from the short-styled plants of the small flowered Margarita Island population. These populations provide two sources of pollen from long-styled plants that have the same incompatibility phenotype yet have markedly different sizes with one pollen source being the same size as compatible pollen. Under the insufficient pollen reserve hypothesis, we would expect that the large pollen from the long-styled plants of the large-flowered Nicaraguan population should be able to grow completely through the styles of long-styled plants of the small-flowered population, since it is the same size as compatible pollen from short-styled plants of the small-flowered population.

We pollinated long-styled plants from the small-flowered population with pollen from long-styled plants of the largeflowered population. Long-styled plants from the smallflowered population were also self-pollinated. Pollen tubes from the large-flowered population grow significantly further into long styles (approx. $1 \mathrm{~mm}$ further), or about $60 \%$ of the distance into the style, compared with self pollen tubes, which grow approximately 50\% the length of the style (Table 8). In no instance did pollen tubes reach the base of the style and seeds were not set. As controls, we carried out compatible crosses between populations, and pollen tubes reached the base of the style when the small-flowered plants were used as maternal parents (for long-styled plants, 19 of 20 styles had tubes at their base, while for short-styled plants 10 of 10 had tubes at their base) indicating that there isn't an interpopulation barrier to compatible pollen tube growth. When plants from the large-flowered population were used as maternal parents, pollen tubes regularly reached the base of the style for short-styled plants (8 of 9 pollinations) and when long-styled plants were used, 9 of 16 styles had pollen tubes at their base. Styles without pollen tubes at their bases usually had few pollen grains on their stigmas.

We also note (Table 2) that the insufficient reserve hypothesis is not well supported because while self pollen tubes do grow somewhat further into styles of long-styled plants, they usually do not travel the distances that would be required to achieve fertilization in styles of short-styled plants (i.e., the length of the longest pollen tube of selfing 
Figs. 5-19. Micrographs of stigmas and styles for selfed long- and short-styled plants of five populations, including three species of Turnera and one species of Piriqueta, fixed $24 \mathrm{~h}$ after pollination. For each species, we show the stigma of a self-pollinated longstyled plant, followed by a self-pollinated short-styled plant (Figs. 6, 9, 12, 15, and 18) first with fluorescence and then the same style using bright field microscopy (Figs. 7, 10, 13, 16, and 19). Selfed long-styled plants show numerous brightly fluorescing callose plugs (Figs. 5, 8, 11, 14, and 17). Note the general lack of callose plugs for short-styled plants but the presence of numerous darkly staining pollen tubes using bright field illumination. Arrows in Fig. 13 indicate pollen tubes that appear to have been disrupted. Figs. 5-7. Turnera scabra, Margarita Island. Figs. 8-10. T. scabra, Dominican Republic. Figs. 11-13. T. joelii. Figs. 14-16. T. grandiflora. Figs. 17-19. Piriqueta caroliniana. Scale bar $=200 \mu \mathrm{m}$.
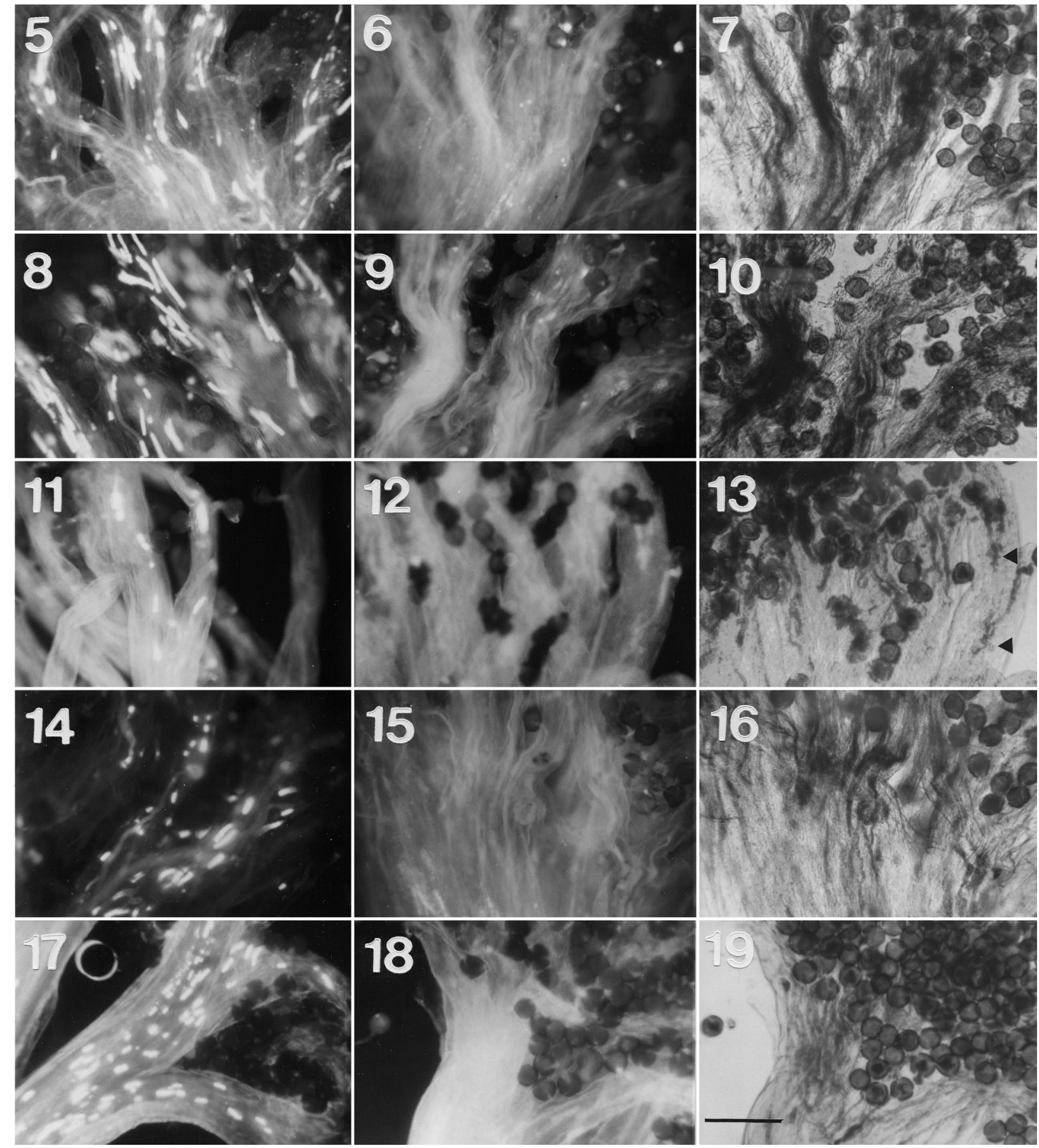

long-styled plants is commonly less than the style length of short-styled plants, although there are some exceptions (e.g., Piriqueta caroliniana).
Crosses of distylous and homostylous species

We tested the recombinant hypothesis for the origin of homostyly by crossing distylous and homostylous species 
Fig. 20. Time course of pollen tube growth following self- and inter-morph crosses for two populations of T. scabra. (a) Mean $( \pm \mathrm{SD})$ pollen tube length for the Nicaraguan population expressed as a percent of style length. $(b)$ Mean $( \pm$ SD) pollen tube length for the Costa Rican population expressed as a percent of style length. $\boldsymbol{\square}$, long-styled, selfed; $\boldsymbol{O}$, short-styled, selfed; $\square$, long-styled, inter-morph cross; $\bigcirc$, short-styled, intermorph cross.
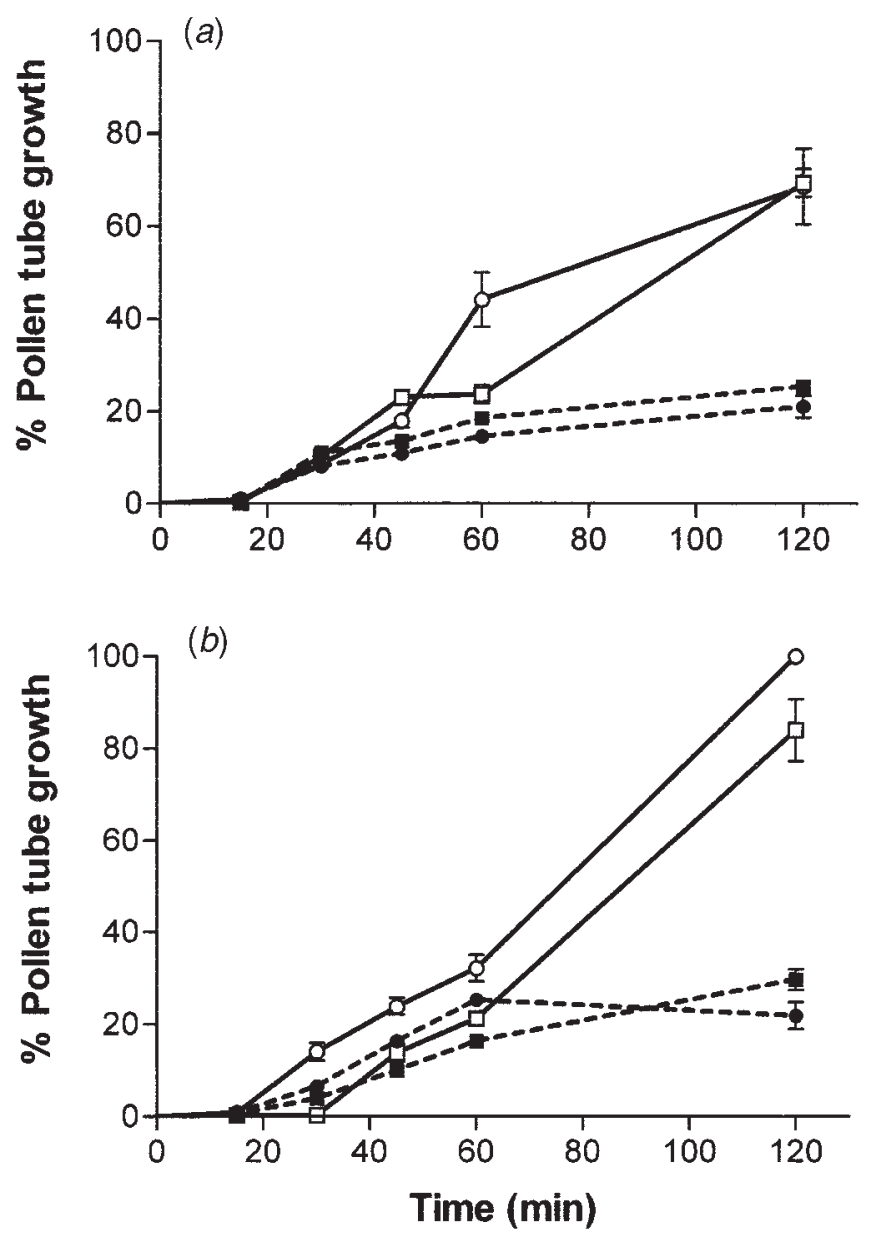

(Figs. 22-26). Data from the crosses are presented as the percent of styles with pollen tubes reaching the base of the style and mean length of the longest pollen tube, expessed as a proportion of total style length (Figs. 27a-h). The percent of styles with tubes at their base reveals that $T$. aurelii, T. velutina, T. ulmifolia, and $P$. cistoides, appear to roughly meet predictions of a crossover mode of origin (Figs. 27a-d). When the homostylous species are used as maternal plants, pollen tubes reach the base of the styles in virtually all styles for the four species, for short-styled pollen donors (e.g., Fig. 22). When pollen from long-styled plants is used there is a low percentage $(14.0 \%)$ of pollen tubes reaching the base of the style for T. velutina (Fig. 27b), while tubes don't reach the base for any of the remaining species (e.g., Fig. 23). When these homostylous species are used as pollen donors, tubes never reach the base of short styles (e.g., Figs. 25-26), but do for long-styled plants (e.g., Fig. 24). The percentage of styles having pollen tubes at their base varies with the cross. Both $T$. aurelii and $T$. velutina show
Fig. 21. Percent of styles possessing pollen tubes with callose plugs following self- and inter-morph timed pollinations of two populations of T. scabra. (a) Nicaraguan population. (b) Costa Rican population. $\mathbf{\square}$, long-styled, selfed; $\boldsymbol{O}$, short-styled, selfed; $\square$, long-styled, inter-morph cross; $\bigcirc$, short-styled, inter-morph cross.
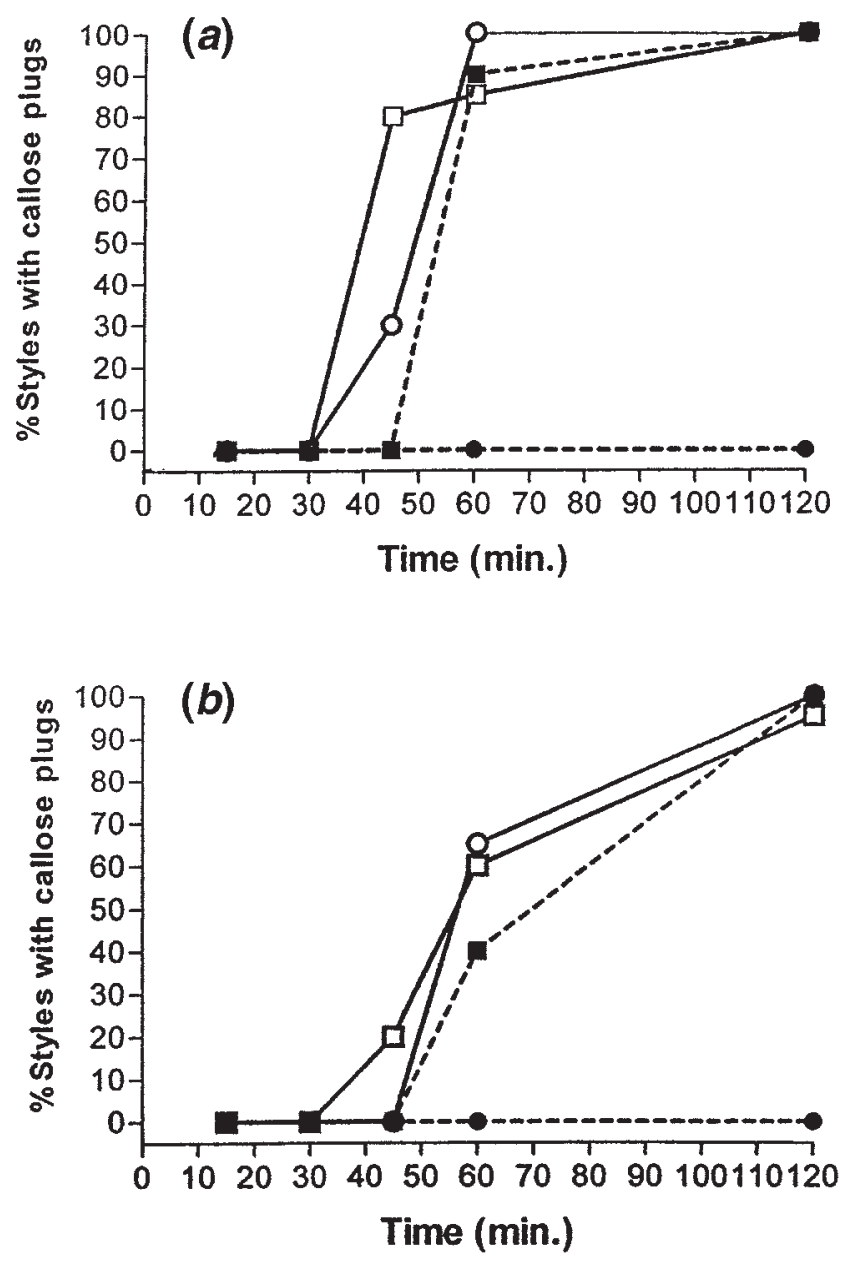

high percentages (100\% and $80 \%$, respectively) while considerably lower percentages occur for $T$. ulmifolia and $P$. cistoides ( $15 \%$ for both species). The quantitative data on mean length of longest pollen tube (Figs. 27a-h), show a pattern consistent with the crossover model of origin. In all four of the above instances pollen tubes from homostyles penetrate further into the styles of long-styled plants compared with penetration of homostyled pollen tubes into the styles of short-styled plants (Figs. $27 a-d$ ).

Turnera acuta, T. cuneiformis, and T. orientalis show more marked deviations from expectations (Figs. 27e-g). A slightly lower percentage of styles have tubes at the base when pollen from long-styled plants is used compared with pollen from short-styled plants. This pattern is mirrored in the longest pollen tube growth data (Figs. 27e-g). When these three homostylous species are used as pollen donors, the results correspond with those expected under the crossover origin model. Turnera ulmifolia from Quaco Rock, Jamaica is unusual in showing no pollen tubes reaching the 
Table 5. Characteristics of Turnera pollen tubes following bud-pollinations fixed $24 \mathrm{~h}$ after pollination.

\begin{tabular}{|c|c|c|c|c|c|c|c|}
\hline Population & Cross & $N$ & $\begin{array}{l}\text { No. style with } \\
\text { tubes at base }\end{array}$ & $G_{\mathrm{df}=3}$ & $\begin{array}{l}\text { Style length } \\
(\mathrm{mm})\end{array}$ & $\begin{array}{l}\text { Majority of } \\
\text { tubes }(\mathrm{mm})\end{array}$ & $\begin{array}{l}\text { Longest } \\
\text { tube }(\mathrm{mm})\end{array}$ \\
\hline \multirow[t]{4}{*}{ Dor7 } & LXL & 15 & 0 & \multirow[t]{4}{*}{$28.1 * * *$} & $9.5 \pm 0.5$ & $1.5 \pm 0.8$ & $1.7 \pm 0.7$ \\
\hline & LXS & 12 & 9 & & $9.3 \pm 0.9$ & $4.8 \pm 4.3$ & $7.7 \pm 3.3$ \\
\hline & SXL & 14 & 7 & & $6.2 \pm 0.4$ & $3.8 \pm 2.8$ & $3.9 \pm 2.8$ \\
\hline & SXS & 20 & 2 & & $5.7 \pm 0.9$ & $1.4 \pm 0.8$ & $2.0 \pm 1.3$ \\
\hline \multirow[t]{4}{*}{ Joli } & LXL & 13 & 0 & \multirow[t]{4}{*}{$30.6 * * *$} & $7.7 \pm 0.7$ & $1.5 \pm 0.4$ & $2.1 \pm 0.7$ \\
\hline & LXS & 17 & 14 & & $7.5 \pm 0.6$ & $6.1 \pm 3.0$ & $6.1 \pm 2.9$ \\
\hline & SXL & 17 & 13 & & $4.4 \pm 0.7$ & $3.2 \pm 1.9$ & $4.1 \pm 1.2$ \\
\hline & SXS & 17 & 12 & & $4.9 \pm 0.9$ & $1.6 \pm 1.8$ & $4.0 \pm 1.7$ \\
\hline \multirow[t]{4}{*}{ Nica } & LXL & 15 & 5 & \multirow[t]{4}{*}{$7.2 \mathrm{~ns}$} & $5.3 \pm 1.7$ & $1.6 \pm 2.8$ & $2.8 \pm 3.4$ \\
\hline & LXS & 15 & 9 & & $3.7 \pm 0.8$ & $2.6 \pm 1.7$ & $2.8 \pm 1.7$ \\
\hline & SXL & 17 & 3 & & $3.6 \pm 1.0$ & $0.9 \pm 1.6$ & $1.2 \pm 1.9$ \\
\hline & SXS & 13 & 3 & & $3.8 \pm 1.0$ & $0.9 \pm 1.5$ & $1.7 \pm 1.9$ \\
\hline \multirow[t]{4}{*}{ Cosr } & LXL & 17 & 0 & \multirow[t]{4}{*}{$11.8 * *$} & $4.4 \pm 1.4$ & $0.7 \pm 0.6$ & $1.7 \pm 1.4$ \\
\hline & LXS & 17 & 6 & & $5.1 \pm 1.9$ & $2.2 \pm 3.3$ & $3.0 \pm 3.1$ \\
\hline & SXL & 17 & 6 & & $3.4 \pm 0.5$ & $0.6 \pm 0.6$ & $2.2 \pm 1.5$ \\
\hline & SXS & 17 & 3 & & $3.4 \pm 0.9$ & $0.7 \pm 1.0$ & $1.6 \pm 1.2$ \\
\hline \multirow[t]{4}{*}{ Mean } & LXL & 60 & 5 & \multirow[t]{4}{*}{$44.7 * * *$} & $6.6 \pm 2.3$ & $1.3 \pm 1.5$ & $2.1 \pm 1.9$ \\
\hline & LXS & 61 & 38 & & $6.2 \pm 2.4$ & $3.9 \pm 3.5$ & $4.8 \pm 3.4$ \\
\hline & SXL & 65 & 29 & & $4.3 \pm 1.3$ & $2.0 \pm 2.3$ & $2.8 \pm 2.2$ \\
\hline & SXS & 63 & 20 & & $4.5 \pm 1.3$ & $1.2 \pm 1.4$ & $2.4 \pm 1.8$ \\
\hline
\end{tabular}

\footnotetext{
abbreviations as in Table 1 .

Note: Number of styles pollinated $(\mathrm{N})$, the number of styles with pollen tubes at their base, and a $G$ test of independence for each population. Values are mean \pm SD for length of style, distance traversed by the majority, and the longest pollen tube. Population

Table 6. Two way ANOVA for pollen tube growth following bud-pollinations.

\begin{tabular}{lrrrrrr}
\hline & \multicolumn{3}{c}{ Majority of tubes } & & \multicolumn{2}{c}{ Longest tubes } \\
\cline { 3 - 4 } \cline { 6 - 7 } Source & df & MS & \multicolumn{1}{c}{$F$} & & MS & \multicolumn{1}{l}{$F$} \\
\hline Cross & 3 & 98.4 & $22.9 * * *$ & & 100.3 & $22.6 * * *$ \\
Population & 3 & 64.3 & $14.9 * * *$ & & 67.7 & $15.3 * * *$ \\
Population $\times$ cross & 9 & 11.8 & $2.7 * *$ & & 22.6 & $5.1 * * *$ \\
Residual & 233 & 4.3 & - & & 4.4 & - \\
\hline$* * P<0.01$. & & & & & \\
$\quad * * * P<0.001$. & & & & &
\end{tabular}

base for any cross, although there is some pollen tube growth into the stigmas and styles for all crosses (Fig. 27h).

For the crosses between homostylous and distylous species, an interesting pattern of callose plug formation occurs (Table 9) consistent with our findings for distylous species (Table 4). Callose plugs occur in all crosses (e.g., Figs. 2224) except when short-styled plants are pollinated with pollen from homostylous species (Table 9; e.g., Fig. 25). Piriqueta cistoides deviates from this pattern and shows a reasonable percentage of callose plug formation for all crosses (although short $\times$ homostyle reveal the smallest percent). The homostylous population from Quaco Rock deviates from this pattern in that callose plugs are not formed when long- or short-styled plants are used as maternal plants. This may be a result of the very limited growth of pollen tubes for these crosses (Fig. 27h).

\section{Discussion}

Pollen tube inhibition following self-pollination for the distylous Turnera and Piriqueta species investigated appears to occur in the stigma or in the upper regions of the style. Differences between the morphs are not very marked, where they do occur, the tendency is for pollen tubes to penetrate somewhat more deeply into the styles of long-styled plants compared with short-styled plants. This is a common pattern among a number of heterostylous species (Dulberger 1992). Our observations are in agreement with findings of Martin (1965) for T. ulmifolia (likely T. scabra), and Rama Swamy and Bahadur (1983) for Turnera subulata, where inhibition often occurred at the juncture of the stigma and style. Shore and Barrett (1984) studied a diploid population of T. subulata and observed somewhat greater penetration of self pollen tubes into styles of long-styled plants, compared to short-styled plants. All of the studies above revealed considerable levels of pollen germination following self pollination of both morphs.

We believe we have found a unique and marked qualitative difference in the presence versus absence of callose plugs upon selfing long-styled as opposed to short-styled plants. Pollen tubes of short-styled plants rarely have callose plugs $24 \mathrm{~h}$ after pollination. This could simply be the result of the reduced growth of incompatible pollen tubes not having sufficient time to form callose plugs for short-styled plants. In some non-heterostylous species, callose plugs are not visible until late in pollen tube development (Knox et al. 1986). No studies to our knowledge, have reported this difference in any heterostylous species, although Scribailo and Barrett (1991) found shorter callose plugs for selfed shortstyled plants, compared to the mid- and long-styled morphs of tristylous Pontederia sagittata. Murray (1990) has shown that in Luculia gratissima, self tubes (of both morphs) show 
Table 7. Mean \pm SD $(\mathrm{mm})$ for reproductive characters comparing two populations of Turnera scabra.

\begin{tabular}{|c|c|c|c|c|c|c|c|}
\hline \multirow[b]{2}{*}{ Population } & \multirow[b]{2}{*}{ Morph } & \multirow[b]{2}{*}{$\begin{array}{l}\text { Flower diameter } \\
(\mathrm{mm})\end{array}$} & \multicolumn{2}{|l|}{ Style } & \multirow[b]{2}{*}{$\begin{array}{l}\text { Stamen length } \\
(\mathrm{mm})\end{array}$} & \multicolumn{2}{|l|}{ Pollen } \\
\hline & & & length $(\mathrm{mm})$ & length $(\mathrm{mm})^{*}$ & & $\begin{array}{l}\text { length } \\
(\mu \mathrm{m})\end{array}$ & $\begin{array}{l}\text { width } \\
(\mu \mathrm{m})\end{array}$ \\
\hline Nica & $\mathrm{S}$ & $55.4 \pm 4.0^{a}$ & $6.7 \pm 0.4^{b}$ & $8.9 \pm 0.5^{b}$ & $16.5 \pm 0.7^{b}$ & $77.6 \pm 1.6^{b}$ & $42.6 \pm 0.9^{b}$ \\
\hline \multirow[t]{2}{*}{ Mrgh } & $\mathrm{L}$ & $32.1 \pm 3.8^{b}$ & $8.8 \pm 0.5^{c}$ & $10.9 \pm 0.8^{c}$ & $7.2 \pm 0.9^{c}$ & $58.6 \pm 1.7^{c}$ & $34.0 \pm 1.2^{c}$ \\
\hline & $\mathrm{S}$ & $34.7 \pm 3.3^{b}$ & $5.2 \pm 0.3^{d}$ & $7.0 \pm 0.5^{d}$ & $10.4 \pm 0.6^{a}$ & $67.9 \pm 2.7^{a}$ & $37.6 \pm 1.1^{a}$ \\
\hline
\end{tabular}

Note: $F$ values from a one way ANOVA are provided. Means sharing the same superscript are not significantly different as determined by Scheffé's test. ANOVA for flower diameter and style lengths were performed with $\mathrm{df}=3,51$. ANOVAs for remaining three traits were performed with df $=3,41$. Population abbreviations as in Table 1 .

*Style length was measured from the base of the ovary.

$* * * P<0.001$.

Table 8. Length of longest pollen tube (mean \pm SD) for long-styled plants of Margarita Isle (Mrgh) that were self-pollinated or pollinated with incompatible pollen from long-styled plants of the large-flowered population of Turnera scabra from Managua (Nica).

\begin{tabular}{llll}
\hline Pollination & $N$ & $\begin{array}{l}\text { Longest tube } \\
\text { length }(\mathrm{mm})^{*}\end{array}$ & $\begin{array}{l}\text { Longest tube length } \\
\text { per style length }\end{array}$ \\
\hline Mrgh long selfed & 19 & $3.7 \pm 0.7$ & $0.49 \pm 0.1$ \\
Mrgh long $\times$ Nica long & 19 & $4.8 \pm 1.5$ & $0.60 \pm 0.2$ \\
\hline${ }^{*} F_{[1,36]}=7.28, P<0.02$. & & \\
${ }^{\dagger} F_{[1,36]}=7.12, P<0.02$. & &
\end{tabular}

Figs. 22-26. Pollen tubes in styles and stigmas for various crosses between distylous and homostylous species fixed $24 \mathrm{~h}$ after pollination. Fig. 22. Pollen tubes at base of style for cross of Turnera aurelii (homostyle) $\times$ T. grandiflora (short-styled plant). Fig. 23. Pollen tube inhibition in the style for the cross $T$. aurelii (homostyle) $\times T$. grandiflora (long-styled plant). Fig. 24. Pollen tubes at the base of the style for the cross of $T$. grandiflora (long-styled plant) $\times T$. aurelii (homostyle). Fig. 25 . Pollen tube inhibition in the stigma, for the cross of $T$. scabra (short-styled plant) $\times$ T. ulmifolia (homostyle). Note the absence of callose plugs. Fig. 26. Bright field illumination of the stigma in Fig. 25, showing darkly stained pollen tubes inhibited in the stigmatic branches. Scale bar $=100 \mu \mathrm{m}$.
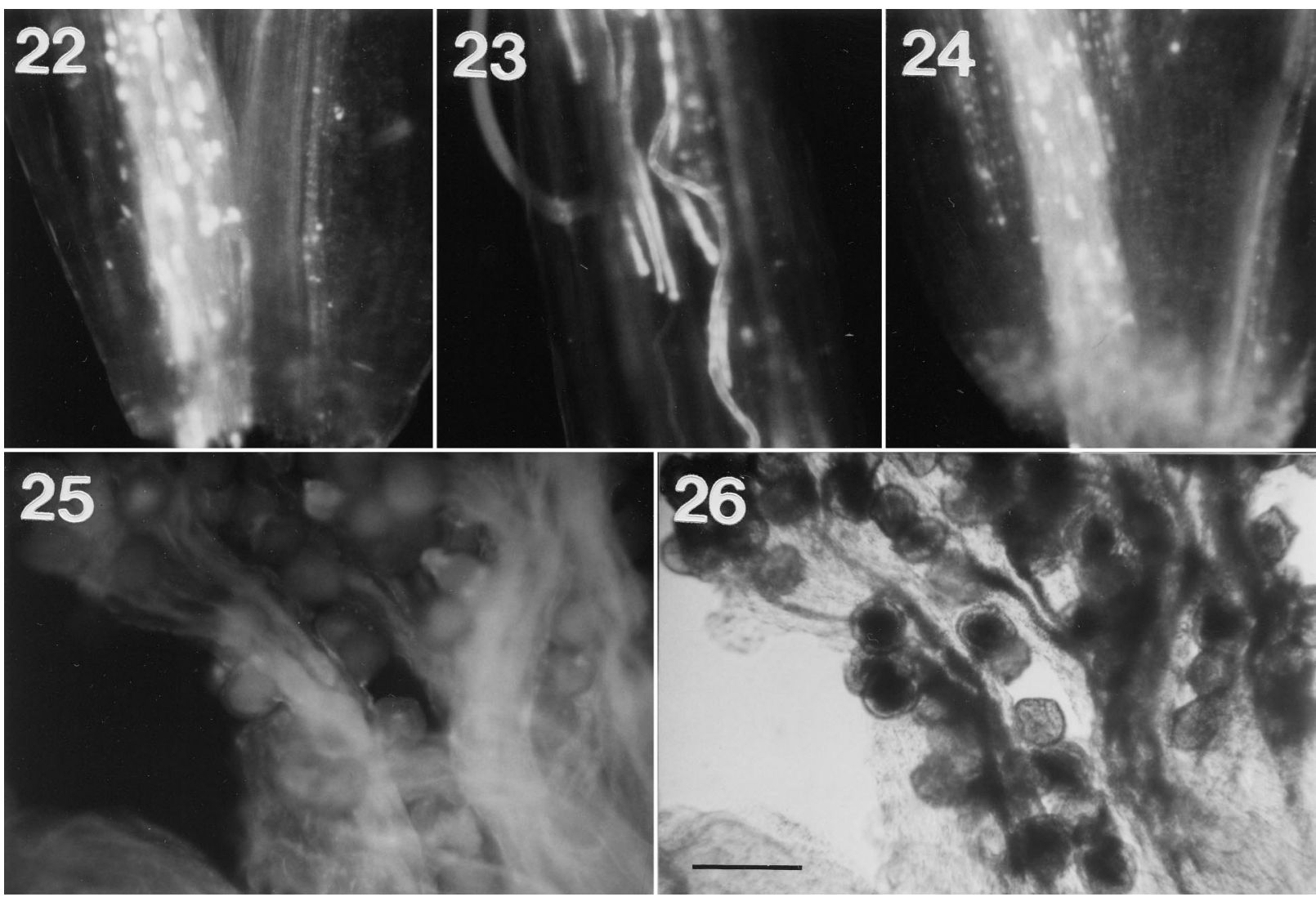
Fig. 27. Histograms of the mean length of the longest pollen tube, expressed as a percent of style length, for crosses between distylous and homostylous species. Numbers above each bar represent the percent of styles with pollen tubes at their base. Black bars represent compatible, and open bars, incompatible pollinations, under predictions from the recombinant origin of homostyles hypothesis. (a). Turnera aurelii $\times$ T. grandiflora. (b). T. velutina $\times$ T. scabra. (c). T. ulmifolia $\times$ T. scabra. $(d)$. Piriqueta cistoides $\times$ P. caroliniana. (e). T. acuta $\times$ T. scabra. $(f)$. T. cuneiformis $\times$ T. scabra. $(g)$. T. orientalis $\times$ T. scabra. $(h)$. T. ulmifolia (Quaco Rock) $\times$ T. scabra. Error bars represent 1 SD.
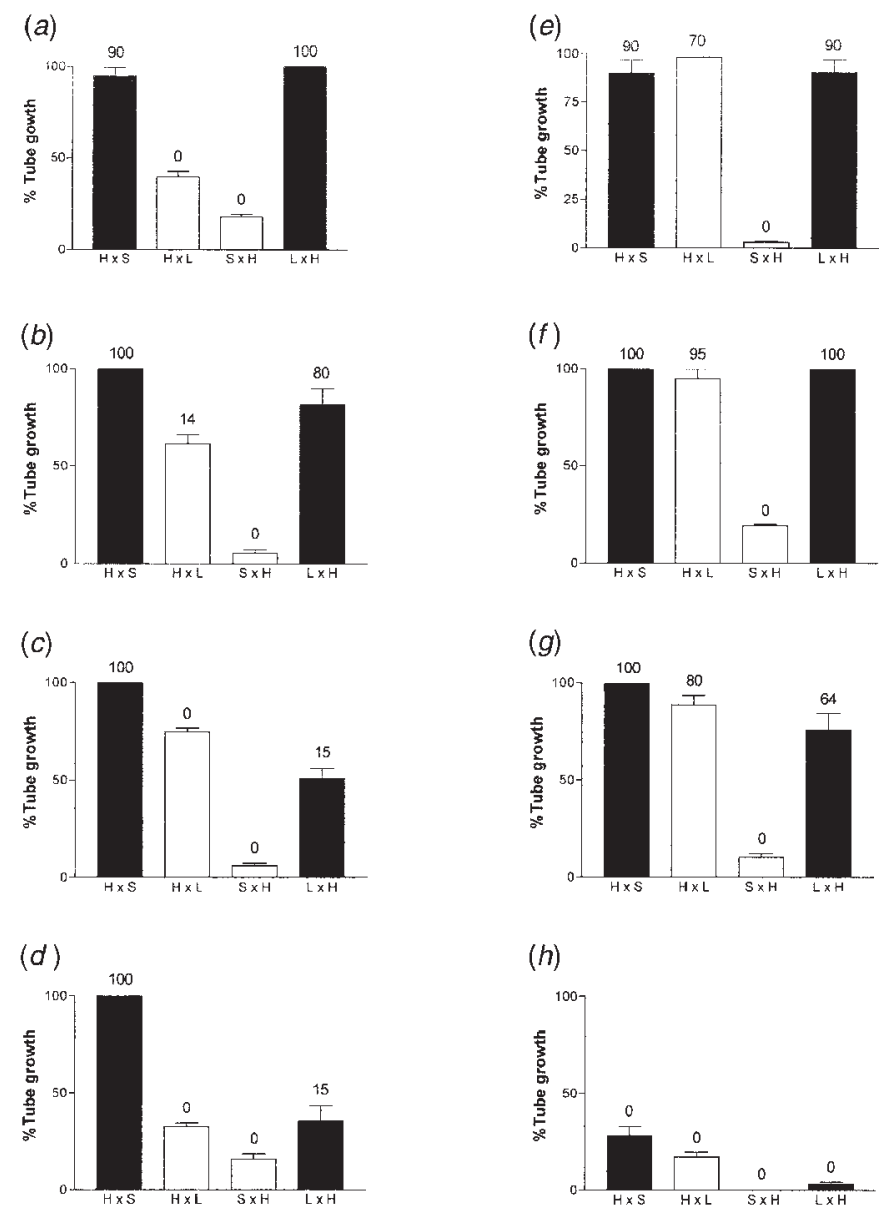

irregular sized callose plugs. Neither Martin (1965) nor Rama Swamy and Bahadur (1983) report the differences we have observed in Turnera spp. Martin (1965) commented that considerable callose is deposited in pollen tubes upon self-pollination but did not comment as to whether there are differences between long- and short-styled plants. We agree that considerable callose is deposited in pollen tubes for selfed long-styled plants, but not for short-styled plants.

Rama Swamy and Bahadur (1983) fixed styles a maximum of $6 \mathrm{~h}$ after pollinations were made. They report that pollen tubes following self-pollination of short-styled plants were thick and irregular with "spathulate tips (callose plugs)." They did not apparently observe this for long-styled plants. We have observed similar unusual and brightly fluorescent pollen tube tips when we examine pollen tubes of some selfed short-styled plants 45 min after self-pollination, but this phenomenon occurs infrequently and we doubt its generality. Pollen tubes tend to fluoresce more brightly when observed a few hours after self-pollination of shortstyled plants, and they do on occasion have a small number of callose plugs. However, $24 \mathrm{~h}$ after pollination, pollen tubes fluoresce poorly, and their walls may be degraded to some degree (Figs. 6, 7, 9, 10, 12, 13, 15, 16, 18, and 19). Both Martin (1965) and Rama Swamy and Bahadur (1983) suggest that pollen tubes have burst. We believe this might be the case for short-styled plants but have not observed this for long-styled plants where pollen tubes appear to be intact $24 \mathrm{~h}$ following self-pollination (Fig. 2).

Our studies monitoring the growth rate of pollen over a $2 \mathrm{~h}$ period reveal that callose plugs rarely seem to form after selfing short-styled plants (i.e., they are not formed initially and then degraded after $24 \mathrm{~h}$ ). Interestingly, when shortstyled plants are pollinated with pollen from homostyles (a cross that is predicted to be incompatible under the crossover model for the origin of homostyles, and should exhibit the same incompatibility response as short selfs), no callose plugs are formed for the Turnera species examined, although they do form in Piriqueta.

We are uncertain of the significance of our discovery, but hypothesize that the lack of callose plug formation for selfed short-styled plants, but not for long-styled plants, is due to different incompatibility mechanisms in the two morphs. This result accords with the discovery of a putative incompatibility protein in the styles of short-styled (but not long-styled) plants of T. scabra, T. subulata, Turnera krapovickassii (Athanasiou and Shore 1997) and recent work in our lab, for $T$. grandiflora and T. joelii.

There has not yet been a definitive discovery of incompatibility proteins in any distylous species. Golynskaya et al. (1976) investigated the effects of style phytohemagglutinins on pollen tube growth and inhibition using in vitro studies of pollen for Primula obconica. Ghosh and Shivanna (1980) reported differences in protein profiles of stigma leachates, but not in homogenized stigmas of Linum grandiflorum. Wong et al. (1994a) identified some candidate incompatibility proteins in Averrhoa carambola (Oxalidaceae) based on the study of a small number of plants of each morph. Athanasiou and Shore (1997) identified a style protein unique to short-styled plants. The protein does not appear in style extracts until $24 \mathrm{~h}$ before anthesis. To test the hypothesis that this short-specific protein might be an incompatibility protein, we carried out a series of bud-pollinations using plants of T. scabra and T. joelii. Our results indicated that in $31.7 \%$ of self-pollinations of short-styled plants pollen tubes reached the base of the style $24 \mathrm{~h}$ after pollination. For budselfed long-styled plants, however, pollen tubes reached the base of the style for $8.3 \%$ of pollinations (Table 5), while the controls showed $44.6 \%$ (short $\times$ long) and $62.3 \%$ (long $\times$ short) of styles had tubes at their bases. Short bud-selfed pollen tubes do reach the base of the styles and these data support the fact that the style protein identified by Athanasiou and Shore (1997) might be an incompatibility protein. We do not feel we can conclude with confidence that this demonstrates that absence of this protein is responsible for this growth, for two reasons. First, the results are to a considerable extent due to the large number of short-selfs leading to pollen tubes at the base of styles for T. joelii. Furthermore, the bud-selfs of short-styled plants did not lead to 
Table 9. Number of styles possessing pollen tubes with callose plugs per total number of styles examined, for crosses between distylous and homostylous Turnera and Piriqueta species.

\begin{tabular}{lccccc}
\hline Cross & $\begin{array}{l}\text { Homostyle } \times \\
\text { long }\end{array}$ & $\begin{array}{l}\text { Homostyle } \times \\
\text { short }\end{array}$ & $\begin{array}{l}\text { Long } \times \\
\text { homostyle }\end{array}$ & $\begin{array}{l}\text { Short } \times \\
\text { homostyle }\end{array}$ & $G_{\mathrm{df}=3}$ \\
\hline Aure $\times$ Gran & $20 / 20$ & $20 / 20$ & $21 / 21$ & $0 / 20$ & $90.5^{* * *}$ \\
Baha $\times$ Cosr & $20 / 20$ & $18 / 20$ & $18 / 20$ & $0 / 20$ & $71.7^{* * *}$ \\
Cune $\times$ Cosr & $19 / 20$ & $20 / 20$ & $20 / 20$ & $0 / 20$ & $84.2^{* * *}$ \\
Velu $\times$ Nica & $21 / 21$ & $20 / 20$ & $20 / 20$ & $0 / 20$ & $90.5^{* * *}$ \\
Orie $\times$ Cosr & $20 / 20$ & $20 / 20$ & $16 / 22$ & $0 / 21$ & $78.9^{* * *}$ \\
Pirh $\times$ Pird & $20 / 20$ & $20 / 20$ & $18 / 20$ & $14 / 20$ & $14.6^{* *}$ \\
Quac $\times$ Cosr & $20 / 21$ & $17 / 20$ & $0 / 20$ & $0 / 20$ & $86.7^{* * *}$ \\
Ulmi $\times$ Cosr & $20 / 20$ & $20 / 20$ & $20 / 20$ & $0 / 20$ & $89.9 * * *$ \\
Pooled & $160 / 162$ & $155 / 160$ & $133 / 163$ & $14 / 161$ & $455.1^{* * *}$ \\
\hline
\end{tabular}

\footnotetext{
Note: Styles were fixed $24 \mathrm{~h}$ after pollination. $G$ tests for independence of proportions for each set of crosses and the pooled data are presented. Population abbreviations as in Table 1.

as great a proportion of pollen tubes at the base of the styles compared to the inter-morph bud-pollinations (Table 5). For a number of pollinations, pollen failed to germinate, perhaps indicating that the stigmas are not entirely receptive $24 \mathrm{~h}$ prior to anthesis.

We exploited the occurrence of a large difference in flower and pollen size between two populations of T. scabra to test the insufficient reserves hypothesis for self-incompatibility of long-styled plants. Our results showed that incompatible pollen tubes from long-styled plants are unable to grow completely through long styles, even if the pollen grains are the same size as those of pollen from short-styled plants. This suggests that long-styled plants must possess an incompatibility system. Coupled with observations by Athanasiou and Shore (1997), who did not detect any proteins unique to long-styled plants, it suggests that there is as yet an undiscovered protein(s) that is likely responsible for incompatibility of long-styled plants.

Shore and Barrett (1985) and Barrett and Shore (1987) showed, using crosses between three homostylous species (T. ulmifolia, T. orientalis, and T. velutina) and distylous species, that these long homostylous species behaved as if they were derived via recombination within a supergene controlling distyly. The styles of the homostyles appear to possess the incompatibility response of long-styled plants, while the pollen had the incompatibility response of short-styled plants. Here we have extended their work by analyzing pollen tube growth and three additional homostylous species. Turnera aurelii is the homostylous species that best meets predictions of the crossover model of origin. Turnera velutina and T. ulmifolia largely meet with its predictions but do show some growth of pollen tubes to the base of styles for $T$. velutina $\times$ long-styled plant (Fig. 27b). Also, there is only a small proportion of styles with pollen tubes at their base for T. ulmifolia and P. cistoides, for long $\times$ homostyle crosses (which should be a compatible cross). Ornduff (1970) has shown that seed set only resulted between crosses of $P$. cistoides and $P$. caroliniana for a single collection of P. cistoides from Trindad. While the data are not provided, Ornduff (1970) indicates that the crosses show unilateral incompatibility with seeds only being formed when $P$. cistoides served as the seed parent (there is no mention of which morph was used in the crosses). In our study, we used pollen tube growth, circumventing difficulties that might arise from seed formation following inter-specfic crosses (immature capsules usually abort when these interspecific crosses are made). Turnera acuta, T. cuneiformis, and T. orientalis all show a deviation from expectations as there is a considerable proportion of tubes at the bases of styles for the supposedly incompatible cross of homostyle $\times$ long-styled plants. Plants of T. ulmifolia from Quaco Rock showed little pollen tube growth for any cross and this population may represent a new species (J.S. Shore, personal communication).

We do not know the phylogenetic relationships among these polyploid homostylous species. Turnera acuta is likely a close relative of T. ulmifolia and it is possible to obtain fertile hybrids among these hexaploid species. Turnera acuta has small flowers and it is tempting to argue that its reduced style length might be responsible for the large proportion of pollen tube growth, however, our data (Table 8) indicate that pollen size alone cannot account for incompatibility. Allohexaploid T. ulmifolia, T. velutina, and T. orientalis are intersterile (Barrett and Shore 1987), and meiotic studies by Fernandez and Arbo (2000a) suggest that T. velutina may share only a single genome in common with $T$. orientalis. Turnera cuneiformis is an octaploid that shares some morphological similarities with $T$. orientalis including small flower size, flower shape, somewhat short-styles, and late anthesis. Fernandez and Arbo (2000b) suggest, based upon observations of chromosome pairing at first metaphase of meiosis, that these two species share three genomes in common. Their shared ancestry could account for the similar behaviour of these two homostylous species. Octaploid T. aurelii, however, also shares these three genomes in common with Turnera cuneiformis and T. orientalis (Fernandez and Arbo $2000 \mathrm{~b}$ ), yet $T$. aurelii conforms to the expectations of the crossover model of origin.

The lack of an apparent "long-styled" incompatibility response in T. acuta, T. cuneiformis, and T. orientalis leads to the rejection of the crossover model of origin for these three species. Alternatively, it is possible that the selfincompatibility response has been lost, following a recombinant origin. Baker (1975) suggested that rearrangement within the supergene that produced the long homostyly of 
Linum lewisii appeared to have been followed by the loss of stylar inhibitory powers to illegitmate pollen from longstyled Linum austriacum or Linum perenne. Baker (1966) proposed a similar scenario for Armeria maritima. Nicholls (1985) suggests that monomorphic populations of Linum tenuifolium are self-compatible, long-styled plants that have arisen without crossing-over within the distyly supergene. For Turnera, our data support a crossover origin of homostyly for some species, however, a detailed investigation of the molecular genetics of distyly and homostyly should allow us to distinguish among various modes of origin of homostyly.

\section{Acknowledgements}

The authors thank Maria Mercedes Arbo for generously providing seeds of a number of Turnera species, Phil Schappert for help in collecting seeds and cuttings of T. ulmifolia from Jamaica, Laurence Packer for use of equipment, and Daphne Goring and Davood Khosravi for helpful advice. This research was funded by a grant from the Natural Sciences and Engineering Research Council of Canada to J.S.S.

\section{References}

Anderson, J.M., and Barrett, S.C.H. 1986. Pollen tube growth in tristylous Pontederia cordata (Pontederiaceae). Can. J. Bot. 64: 2602-2607.

Athanasiou, A., and Shore, J.S. 1997. Morph-specific proteins in pollen and styles of distylous Turnera (Turneraceae). Genetics, 146: 669-679.

Baker, H.G. 1966. The evolution, functioning, and breakdown of heteromorphic incompatibility systems. I. The Plumbaginaceae. Evolution, 20: 349-368.

Baker, H.G. 1975. Sporophyte-gametophyte interactions in Linum and other genera with heteromorphic incompatibility. In Gamete competition in plants. Edited by D.L. Mulcahy. North-Holland Publishing Co., Amsterdam. pp. 191-199.

Barrett, S.C.H. 1992. Heterostylous genetic polymorphisms: model systems for evolutionary analysis. In Evolution and function of heterostyly. Edited by S.C.H. Barrett. Springer-Verlag, New York. pp. 1-29.

Barrett, S.C.H. 1998. The evolution of mating strategies in flowering plants. Trends Plant Sci. 3: 335-341.

Barrett, S.C.H., and Cruzan, M.B. 1994. Incompatibility in heterostylous plants. In Genetic control of self-incompatibility and reproductive development in flowering plants. Edited by E.G. Williams, A.E. Clarke, and R.B. Knox. Kluwer Academic Publishers, Boston. pp. 189-217.

Barrett, S.C.H., and Shore, J.S. 1987. Variation and evolution of breeding systems in the Turnera ulmifolia L. complex (Turneraceae). Evolution, 41: 340-354.

Bawa, K.S., and Beach, J.H. 1983. Self-incompatibility systems in the Rubiaceae of a tropical lowland wet forest. Am. J. Bot. 70: 1281-1288.

Dowrick, V.P.J. 1956. Heterostyly and homostyly in Primula obconica. Heredity, 10: 219-236.

Dulberger, R. 1964. Flower dimorphism and self-incompatibility in Narcissus tazetta L. Evolution, 18: 361-363.

Dulberger, R. 1975a. Intermorph structural differences between stigmatic papillae and pollen grains in relation to incompatibility in Plumbaginaceae. Proc. R. Soc. London, Ser. B, 188: 257-274.
Dulberger, R. 1975b. S-gene action and the significance of characters in the heterostylous syndrome. Heredity, 35: 407-415.

Dulberger, R. 1992. Floral polymorphisms and their functional significance in the heterostylous syndrome. In Evolution and function of heterostyly. Edited by S.C.H. Barrett. Springer-Verlag, New York. pp. 41-84.

Ernst, A. 1955. Self-fertility in monomorphic Primulas. Genetica, 27: 391-448.

Fernandez, A. 1987. Estudios cromosomicos en Turnera y Piriqueta (Turneraceae). Bonplandia, 6: 1-21.

Fernandez, A., and Arbo, M.M. 2000a. Relaciones genómicas entre dos especies hexaploides de Turnera, T. orientalis y T. velutina, y una diploide, T. grandiflora (Turneraceae, serie Turnera). Bonplandia, 10: 181-187.

Fernandez, A., and Arbo, M.M. 2000b. Cytogenetic relationships between Turnera aurelii, T. cuneiformis $(2 \mathrm{n}=8 \times=40)$ and T. orientalis $(2 \mathrm{n}=6 \mathrm{x}=30)$ (Turneraceae). Cytologia, 65: 97-102.

Ghosh, S., and Shivanna, K.R. 1980. Pollen-pistil interaction in Linum grandiflorum. Planta, 149: 257-261.

Golynskaya, E.L., Bashkirova, N.V., and Tomchuk, N.N. 1976. Phytohemagglutinins of the pistil in Primula as possible proteins of generative incompatibility. Sov. Plant Physiol. 23: 169-176.

Knox, R.B., Williams, E.G., and Dumas, C. 1986. Pollen, pistil, and reproductive function in crop plants. In Plant breeding reviews, Vol. 4. Edited by J. Janick. AVI publishing Co., Westport, Conn. pp. 9-79.

Lewis, D. 1982. Incompatibility, stamen movement and pollen economy in a heterostyled tropical forest tree, Cratoxylum formosum (Guttiferae). Proc. R. Soc. London, Ser. B, 214: 273-283.

Lloyd D.G., and Webb, C.J. 1992. The evolution of heterostyly. In Evolution and function of heterostyly. Edited by S.C.H. Barrett. Springer-Verlag, New York. pp. 151-178.

Martin, F.W. 1959. Staining and observing pollen tubes in the style by means of fluorescence. Stain Technol. 34: 125-128.

Martin, F.W. 1965. Distyly and incompatibility in Turnera ulmifolia. Bull. Torrey Bot. Club, 92: 185-192.

Mather, K., and de Winton, D. 1941. Adaptation and counter-adaptation of the breeding system in Primula. Ann. Bot. 5: 299-311.

Murray, B.G. 1990. Heterostyly and pollen-tube interactions in $\mathrm{Lu}$ culia gratissima (Rubiaceae). Ann. Bot. 65: 691-698.

Nicholls, M.S. 1985. The evolutionary breakdown of distyly in Linum tenuifolium (Linaceae). Plant Syst. Evol. 150: 291-301.

Ornduff, R. 1970. Relationships in the Piriqueta caroliniana P. cistoides complex (Turneraceae). J. Arnold Arboretum, 51: 492-498.

Rama Swamy, N., and Bahadur, B. 1983. Pollen tube growth studies in self- and cross-pollinated pistils of distylous Turnera subulata (Turneraceae). J. Biol. Res. 3: 57-63.

Sage, T.L., Strumas, F., Cole, W.W., and Barrett, S.C.H. 1999. Differential ovule development following self- and cross-pollination: the basis of self-sterility in Narcissus triandrus (Amaryllidaceae). Am. J. Bot. 86: 855-870.

SAS. 1996. SAS/STAT User's Guide, Release 6.03 ed. SAS Institute Inc., Cary, N.C.

Schoch-Bodmer, H. 1934. Zum Heterostylieproblem: Griffelbeschaffenheit und Pollenschlauchwachstum bei Fagopyrum esculentum. Planta, 22: 149-152.

Schou, O., and Philipp, M. 1983. An unusual heteromorphic incompatibility system. II. Pollen tube growth and seed sets following compatible and incompatible crossing within Anchusa officinalis L. (Boraginaceae). In Pollen: biology and implications for plant breeding. Edited by D.L. Mulcahy and E. Ottaviano. Elsevier, New York. pp. 219-227. 
Scribailo, R.W., and Barrett, S.C.H. 1991. Pollen-pistil interactions in tristylous Pontederia sagittata (Pontederiaceae). II. Patterns of pollen tube growth. Am. J. Bot. 78: 1662-1682.

Shivanna, K.R., Heslop Harrison, J., and Heslop Harrison, Y. 1981. Heterostyly in Primula. 2. Sites of pollen inhibition and effects of pistil constituents on compatible and incompatible pollen tube growth. Protoplasma, 107: 319-337.

Shore, J.S., and Barrett, S.C.H. 1984. The effect of pollination intensity and incompatible pollen on seed set in Turnera ulmifolia (Turneraceae). Can. J. Bot. 62: 1298-1303.

Shore, J.S., and Barrett, S.C.H. 1985. The genetics of distyly and homostyly in Turnera ulmifolia L. (Turneraceae). Heredity, 55: 167-174.
Urban, I. 1883. Monographie der Familie der Turneraceen. Jahrb. Bot. Gard. Berlin. 2: 1-152.

Wedderburn, F.M., and Richards, A.J. 1990. Variation in withinmorph incompatibility inhibition sites in heteromorphic Primula. New Phytol. 116: 149-162.

Wong, K. C., Watanabe, M., and Hinata, K. 1994a. Protein profiles in pin and thrum floral organs of distylous Averrhoa carambola L. Sex. Plant Reprod. 7: 107-115.

Wong, K. C., Watanabe, M., and Hinata, K. 1994b. Fluorescence and scanning electron microscopic study on self-incompatibility in distylous Averrhoa carambola L. Sex. Plant Reprod. 7: 116-121. 